\title{
ANALISA PENERAPAN BALANCE SCORECARD TERHADAP KINERJA PERUSAHAAN PADA PT MALINDO FEEDMILL TBK
}

\author{
*Pratiwi \\ **Elok Kurniawati

\section{Universitas Mercu Buana Jakarta}

\section{ARTICLE INFO}

Keywords:

Balance Scorecard and Performance Measurement

\begin{abstract}
This study aims to analyze the development of performance measurement systems at PT Malindo Feedmill Tbk and to find out the application of Balance Scorecard as a performance measurement system at PT Malindo Feedmill Tbk. This performance measurement is seen from a financial and non-financial perspective. This research was obtained from interviews, distributing questionnaires and observations. Data collection uses primary and secondary data. Primary data obtained from respondents of employees and customers of PT Malindo Feedmill Tbk. Secondary data is obtained from the annual report of PT Malindo Feedmill Tbk. Analysis and interpretation of nonfinancial terms are said to be good. While in terms of nonfinancial, although there is a fluctuation of financial ratios, it can be said to be quite good.
\end{abstract}

\section{ABSTRAK}

Penelitian ini bertujuan untuk menganalisis perkembangan sistem pengukuran kinerja pada PT Malindo Feedmill Tbk dan untuk mengetahui penerapan Balance Scorecard sebagai suatu sistem pengukuran kinerja pada PT Malindo Feedmill Tbk. Pengukuran kinerja ini dilihat dari segi keuangan dan juga segi non keuangan. Penelitian ini diperoleh dari wawancara, menyebarkan kuisioner dan pengamatan (observasi). Pengumpulan data menggunakan data primer dan sekunder. Data primer diperoleh dari responden karyawan dan pelanggan PT Malindo Feedmill Tbk. Data sekunder diperoleh dari laporan tahunan PT Malindo Feedmill Tbk. Analisa dan interprestasi dari segi non keuangan dikatakan baik. Sedangkan dari segi nonfinancial, walaupun terjadi naik turun terhadap rasio keuangan dapat dikatakan cukup baik.

\section{How to Cite:}

Pratiwi dan Elok Kurniawati. Analisa Penerapan Balance Scorecard Terhadap Kinerja Perusahaan pada PT Malindo Feedmill Tbk. Jurnal Ilmiah Wahana Akuntansi, 14(1), 65-84. https://doi.org/10.21009/wahana.014.1.5

Corresponding Author: 
Pratiwi dan Elok Kurniawati/ Jurnal Ilmiah Wahana Akuntansi, 14 (1) 2019, 65-84

\section{PENDAHULUAN}

Era globalisasi yang berkembang saat ini menimbulkan persaingan antar perusahaan di bidang peternakan. Hal ini timbul dikarenakan banyak para perusahaan besar yang menguasai pasar di Indonesia dengan bidang yang sama. Menurut Syarkawi Rauf, ketua Komisi Pengamat Persaingan Usaha (KPPU) mengungkapkan industri unggas Indonesia dikuasai oleh para perusahaan perunggasan besar (diakses pada kompas.com, 2016). Perusahaan tersebut diantaranya merupakan perusahaan yang sudah terdaftar pada BEI, seperti: Charoen Pokphand Indonesia, Japfa Comfeed Indonesia, Malindo Feedmill, dan Sierad Produce Tbk. Dengan adanya persaingan di bidang bisnis yang sama, maka tak dapat dipungkiri setiap usaha memiliki tujuan

untuk menguasai segmen pasar guna memperoleh pendapatan yang maksimal. Untuk memperoleh tujuan tersebut maka tiap perusahaan memerlukan strategi yang baik.

Menurut Rangkuti (2013), Rahasia sukses strategi bisnis kelas dunia adalah bekerja berdasarkan rencana yang tepat, memiliki tujuan yang jelas, transparan dan terukur. Pencapaian perusahaan yang terukur tersebut memberikan kejelasan bagi setiap unit kerja dan setiap orang tentang sasaran yang harus dicapai dan apa yang harus dilakukan untuk mencapai sasaran tersebut. Namun, selama ini banyak perusahaan yang melakukan pengukuran kinerja dari segi finansial dengan menggunakan indikator rasio keuangan. Indikator tersebut kurang memadai dalam proses pengukuran kinerja perusahaan karena kurang mewakili dalam memberikan suatu penilaian terhadap perkembangan suatu perusahaan (Ami dan Muhammad, 2015).

Menajemen perlu sistem pengendalian meliputi ukuran kinerja finansial dan nonfinansial dalam usahanya (Anthony \& Govindarajan, 2016:10). Pengukuran kinerja finansial dan non finansial tersebut dikenal dengan metode Balanced Scorecard. Menurut Parmenter (2014:17), Balanced Scorecard merupakan sebuah alat ukur kinerja secara lebih menyeluruh, meliputi empat prespektif. Perspektif tersebut antara lain: 1) perspektif finansial, 2) perspektif pelanggan, 3) perspektif proses bisnis

internal, dan 4) perspektif pembelajaran dan pertumbuhan.

PT Malindo Feedmill Tbk merupakan salah satu perusahaan bergerak dibidang peternakan yang selalu mengembangkan potensi usahanya dimasa yang akan datang. Oleh karena itu, perusahaan ini perlu mengukur tingkat kinerja perusahaan secara meluas agar dapat menjadi bahan evaluasi bagi manajemen dalam mengembangkan usahanya di era gobalisasi ini.

Tabel 1 di bawah ini menyajikan Rasio Keuangan PT Malindo Feedmill Tbk periode 2015-2017. 
Pratiwi dan Elok Kurniawati/ Jurnal Ilmiah Wahana Akuntansi, 14 (1) 2019, 65-84

Tabel 1

Rasio Keuangan PT Malindo Feedmill Tbk Periode 2015-2017

\begin{tabular}{|l|r|r|r|}
\hline \multicolumn{1}{|c|}{ Rasio } & $\mathbf{2 0 1 5}$ & $\mathbf{2 0 1 6}$ & $\mathbf{2 0 1 7}$ \\
\hline ROI & $-2 \%$ & $6 \%$ & $1 \%$ \\
\hline ROE & $-5 \%$ & $12 \%$ & $3 \%$ \\
\hline Net Profit Margin & $-2 \%$ & $4 \%$ & $1 \%$ \\
\hline
\end{tabular}

Sumber: Annual Report 2017 PT Malindo Feedmill Tbk

Berdasarkan data di atas rasio keuangan PT Malindo Feedmill Tbk pada tahun 2017 mengalami penurunan. Melihat kondisi tersebut perusahaan hanya dapat menilai kinerja perusahaan menurun dari segi finansial saja. Namun belum tentu dari segi perspektif lainnya memiliki kinerja yang menurun juga. Perusahaan pun perlu menilai kinerja dari setiap unitnya dan tidak hanya melihat dari segi keuangannya saja, sehingga perusahaan dapat mengevaluasi kinerja secara meluas dan terukur. Oleh karena itu, perusahaan pun perlu memiliki tolak ukur yang dapat berkesinambung antara keempat perspektif tersebut yakni dengan metode Balance Scorecard.

\section{Perumusan Masalah}

Berdasarkan latar belakang penelitian yang telah diuraikan, maka penelitian ini merumuskan pokok masalah yaitu bagaimana analisa kinerja PT Malindo Feedmill Tbk jika dinilai dengan metode Balance scorecard dalam perspektif keuangan, perspektif pelangan, perspektif internal bisnis proses, dan perspektif permbelajaran \& pertumbuhan?

\section{Tujuan Penelitian}

Berdasarkan rumusan masalah di atas, tujuan penelitian ini adalah untuk mngetahui hasil analisis kinerja PT Malindo Feedmill Tbk jika dinilai dengan metode Balance scorecard dalam perspektif keuangan, perspektif pelangan, perspektif internal bisnis proses, dan perspektif permbelajaran \& pertumbuhan?

\section{KAJIAN PUSTAKA DAN KERANGKA PEMIKIRAN}

Menurut Anthony dan Govindarajan (2012), teori agensi adalah hubungan atau kontrak antara principal dan agent. Teori agensi memiliki asumsi bahwa tiap-tiap individu semata-mata termotivasi oleh kepentingan dirinya sendiri sehingga menimbulkan konflik kepentingan antara principal dan agent.

Ghozali dan Chariri (2007:409) menyatakan bahwa dalam Stakeholder Theory Perusahaan bukanlah entitas yang hanya beroperasi untuk kepentingannya sendiri namun harus memberikan manfaat bagi para stakeholder (pemegang saham, kreditor, konsumen, supplier, pemerintah, masyarakat, dan pihak lain). Dengan demikian, maka keberadaan suatu perusahaan sangat dipengaruhi oleh dukungan yang 
Pratiwi dan Elok Kurniawati/ Jurnal Ilmiah Wahana Akuntansi, 14 (1) 2019, 65-84

diberikan oleh stakeholder kepada perusahaan tersebut.

Keterkaitan antara teori keagenan dan Balanced Scorecard yaitu pemegang saham (principal) memberikan tugas atau wewenang kepada manajemen perusahaan (agen).

Manajemen perusahaan menjalankan wewenang tersebut dengan menggunakan sistem Balanced Scorecard selama periode yang telah ditetapkan. kemudian Pemilik menilai kinerja manajemen perusahaan, apakah sesuai dengan target yang ditetapkan. Jika kinerja managemen tercapai maka akan mendapatkan keuntungan berupa reward, begitu sebaliknya juga menguntungkan bagi para pemilik usaha. Dikarenakan usaha memerlukan pihak atau relasi dari berbagai pihak luar, maka keterkaitan teori stakeholder ini mendukung dalam konsep metode balance scorecard yang merupakan sebuah tolak ukur yang terdiri dari prespektif keuangan, pelanggan, internal bisnis proses dan pembelajaran \& petumbuhan. Jika pihak manajemen dapat memenuhi kinerja sesuai tingkat pencapaian tiap perspektif tersebut maka dapat memenuhi kebutuhan para stakeholder dan lebih meningkatkan hubungan yang baik satu sama lain.

Menurut Atkinson et al. (2012:111) pengukuran kinerja adalah alat yang kuat untuk mengkomunikasikan dengan jelas dan tanpa keraguan apa yang dimaksud perusahaan terkait pernyataan tujuan, misi dan visi strategisnya. Salah satunya metode pengukuran kinerja yang terarah, terukur dan meluas adalah Balance Scorecard. Metode ini pertama kali dikemukakan oleh David P. Norton sebagai CEO Nolan Norton dan Robert S. Konsep balance scorecard menekankan pada keseimbangan faktor keuangan dan non keuangan.

Dalam Buku Handoko (2012:398), Prestasi dan kondisi keuangan suatu perusahaan perlu dinilai dengan ukuranukuran tertentu. Ukuran yang sering kali dipergunakan adalah rasio atau indeks, yang menunjukkan hubunganantara dua data keuangan akan memberikan penilaian atas dasar data dan informasi yang diperoleh dari Laporan keuangan, yang ditunjukkan dalam bentuk rasio-rasio atau prosesntasi. Rasiorasio tersebut antara lain:

1. Rasio likuiditas yang mengukur kemampuan perusahaan untuk memenuhi kewajiban keuangan (finansial) jangka pendek

2. Rasio laverage (atau disebut debtmnagement ratios), yang menunjukan kemampuan perusahaan untuk memenuhi kewajiban-kewajiban jangka panjang, atau mengukur seberapa jauh perusahaan dibelanjai dengan hutang

3. Rasio profitabilitas, yang mengukur performance atau efektiftas manajemen secara keseluruhan sebagaimana ditunjukkan oleh laba yang diperoleh dari penjualan dan investasi 
Pratiwi dan Elok Kurniawati/ Jurnal Ilmiah Wahana Akuntansi, 14 (1) 2019, 65-84

Dalam perspektif pelanggan, pengukuran dilakukan dengan lima aspek utama (Anthony \& Govindarajan, 2012), yaitu:

1. Market Share yaitu mengetahui seberapa kemampuan dalam menguasai segmen pasar

2. Customer Retention yaitu mengukur kemampuan mempertahankan pelanggan.

3. Customer Acquisition (Akuisisi Pelanggan)

4. Customer Satisfaction yaitu mengukur tingkat kepuasan pelanggan

5. Customer Profitability yaitu mengukur laba bersih dari seorang pelanggan / segmen setelah dikurangi biaya yang khusus diperlukan untuk mendukung pelanggan tersebut.

Balanced Scorecard terdiri dari tiga model dari proses bisnis utama (Anthony \& Govindarajan, 2012)., yaitu:

1. Proses Inovasi, dalam proses ini penciptaan nilai tambah bagi konsumen, proses inovasi merupakan salah satu kritikal proses yang mana efisiensi dan efektivitas serta ketepatan waktu dari proses inovasi akan mendorong nilai tambah bagi konsumen.

2. Proses Operasi, pada proses operasi yang dilakukan oleh perusahaan adalah menitikberatkan pada efesiensi proses, konsistensi dan ketepatan waktu dari barang dan jasa yang diberikan kepada konsumen.

3. Proses Layanan Purna Jual. Proses ini mengukur kemampuan perusahaan dalam meberikan garansi dan perbaikan penanganan atas barang yang rusak dan yang dikembalikan.

Dalam berbagai kasus, perspektif Pembelajaran dan pertumbuhan merupakan pondasi keberhasilan bagi knowledge-worker organization dengan tetap memperhatikan faktor sistem dan organisasi. Dalam perspektif ini, mengidentifikasi struktur yang harus dibangun, meliputi: kepuasan kerja, retensi pekerja dan produktivitas pekerja

\section{Kerangka Pemikiran}

Berdasarkan landasan teori yang telah dikemukakan di atas, maka kerangka pemikiran dari penelitian ini disajikan pada Gambar 1 di bawah ini.

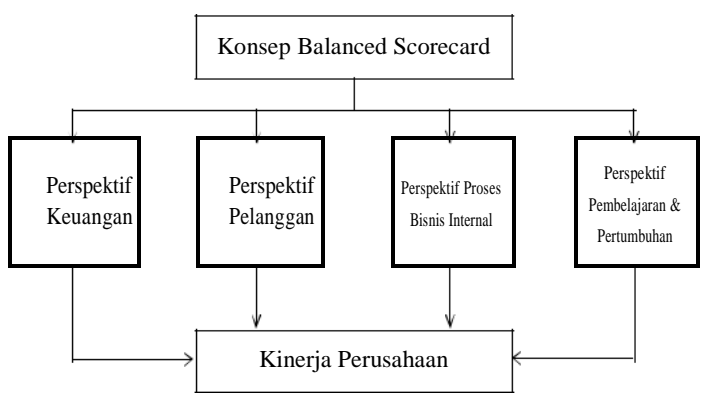

Gambar 1

\section{Kerangka Pemikiran Penelitian}

Sumber: Data diolah penulis, tahun 2018 
Pratiwi dan Elok Kurniawati/ Jurnal Ilmiah Wahana Akuntansi, 14 (1) 2019, 65-84

\section{OBJEK DAN METODOLOGI PENELITIAN}

\section{Tahapan Penelitian}

Pendekatan yang digunakan adalah pendekatan deskriptif kualitatif yaitu proses pemecahan masalah yang diselidiki dengan menjabarkan atau melukiskan kondisi subyek dan obyek penelitian pada periode penelitian berdasarkan fakta-fakta yang nampak atau sebagaimana adanya.

Deskriptif kuantitatif yaitu penelitian ilmiah yang sistematis terhadap bagianbagian dan fenomena serta hubunganhubungannya. Tujuan penelitian kuantitatif adalah mengembangkan dan menggunakan model-model matematis.

\section{Jenis Data, Tempat, dan Waktu Penelitian}

Data yang digunakan adalah data primer Data bersumber dari hasil pengamatan (observasi) dan wawancara (interview) dengan sejumlah karyawan PT Malindo Feedmill (Tbk).

Selain itu, peneliti juga menggunakan angket atau kuesioner sebagai sumber data primer. Kuisioner dibagikan kepada 100 responden untuk penyebaran kuesionernya. Teknik pengambilan sampel dalam penelitian ini adalah dengan menggunakan metode simple random sampling. Teknik penentuan sampel secara acak, karena setiap anggota populasi mempunyai peluang yang sama tanpa memperhatikan strata yang ada dalam populasi.
Tekik Pengumpulan Data dan Operasionalisasi Variabel

Penelitian ini menggunakan cara pengumpulan data primer dilakukan dengan metode survei menggunakan media angket (kuesioner). Untuk mengukur pendapat responden digunakan Skala Likert lima angka. Skala Likert lima angka yaitu mulai angka 5 (Sugiyono, 2014:314), dengan rincian sebagai berikut:

1. Kategori Sangat Setuju (SS) diberi skor 5

2. Kategori Setuju (S) diberi skor 4

3. Kategori Netral (N) diberi skor 3

4. Kategori Tidak Setuju (TS) diberi skor 2

5. Kategori Sangat Tidak Setuju (TST) diberi skor 1

Operasionalisasi variabel penelitian ini terdapat pada Lampiran 1.

\section{Metode Penelitian}

Pada penelitian analisis data dilakukan dengan melakukan pengujian uji validitas dan reliabilitas data kuisioner, selanjutnya dilakukan analisa data kuisioner dengan menggunakan tabel kategori interprestasi skor dan menganalisa kirnerja keuangan dengan melihat hasil rasio keuangan dalam 3 tahun periode.

\section{PEMBAHASAN \\ Perspektif Keuangan}


Pratiwi dan Elok Kurniawati/ Jurnal Ilmiah Wahana Akuntansi, 14 (1) 2019, 65-84

Perspektif keuangan dianalisis dengan menggunakan rasio keuangan milik PT Malindo Feedmill Tbk seperti yang disajikan pada Tabel 2 di bawah ini.

Tabel 2

\section{Analisis Perspektif Keuangan}

PT Malindo Feedmill Tbk

\begin{tabular}{|l|c|c|c|}
\hline \multirow{2}{*}{} & \multicolumn{3}{|c|}{ Periode } \\
\cline { 2 - 4 } & $\begin{array}{c}\mathbf{2 0 1} \\
\mathbf{5}\end{array}$ & $\begin{array}{c}\mathbf{2 0 1} \\
\mathbf{6}\end{array}$ & $\mathbf{2 0 1 7}$ \\
\hline Current Ratio & 1,26 & 1,21 & 0,91 \\
\hline Net Profit Margin & $-2 \%$ & $4 \%$ & $1 \%$ \\
\hline ROA & $-2 \%$ & $6 \%$ & $1 \%$ \\
\hline ROE & $-5 \%$ & $12 \%$ & $3 \%$ \\
\hline
\end{tabular}

Sumber: Annual Report 2017 PT Malindo Feedmill Tbk

Berdasarkan data pada tabel diatas, Pada tahun 2017, rasio ini mengalami penurunan sebesar 0,3 dibanding tahun 2016 . Menurut Handoko (2012:399), rata-rata industri untuk rasio lancar ini adalah sebesar 2,1 . Walaupun masih belum dapat mencapai nilai rata-rata sesuai teori tersebut, akan tetapi kinerja perusahaan dari rasio lancar ini masih dikatakan cukup baik, karena rasio yang dihasilkan masih dalam kategori positif. Hal ini berarti perusahaan masih mampu untuk memenuhi kewajiban keuangan jangka pendeknya.

Melihat kondisi Net Profit Margin PT Malindo Feedmill Tbk di tabel diatas, tahun 2017 mengalami penurunan sebesar 3\% sehingga Net Profit Margin yang didapat sebesar 1\%. Menurut Handoko (2012: 399), rata-rata industri untuk net profit margin adalah sebesar 9\%. Walaupun net profit margin perusahaan ini masih belum dapat mencapai nilai rata-rata industri sesuai teori tersebut, akan tetapi kinerja perusahaan berdasarkan rasio net profit margin ini masih dikatakan cukup baik karena rasio yang dihasilkan masih dalam kategori positif. Hal ini berarti perusahaan masih mampu menghasilkan pendapatan $1 \%$ dari tiap penjualannya.

Melihat kondisi ROA PT Malindo Feedmill Tbk pada tabel diatas, pada tahun 2017, rasio ROA mengalami penurunan sebesar 5\% dibandingkan tahun 2016. Menurut Handoko (2012:399), rata-rata industri rasio ROA adalah $13 \%$. Walaupun rasio ROA perusahaan ini masih belum mencapai nilai rata-rata industri sesuai teori tersebut, akan tetapi kinerja perusahaan berdasarkan rasio ROA ini masih dikatakan cukup baik karena rasio yang dihasilkan masih dalam kategori positif. Hal ini berarti perusahaan masih mampu mendapatkan laba sebesar $1 \%$ dari aktiva yang dimilikinya.

Melihat kondisi rasio return of equity ROE pada tabel diatas, tahun 2017, ROE tersebut mengalami penurunan menjadi sebesar 3\%. Menurut Handoko (2012:399), rata-rata industri untuk rasio ROE sebesar 21,6\%. Walaupun rasio ROE perusahaan ini masih belum mencapai nilai rata-rata industri sesuai teori tersebut, akan tetapi kinerja perusahaan berdasarkan rasio ROE ini masih dikatakan cukup baik karena rasio yang 
Pratiwi dan Elok Kurniawati/ Jurnal Ilmiah Wahana Akuntansi, 14 (1) 2019, 65-84

dihasilkan masih dalam kategori positif. Hal ini berarti perusahaan masih mampu mendapatkan laba sebesar $3 \%$ dari modal yang dimilikinya.

\section{Perspektif Non Keuangan}

Perspektif non keuangan dianalisis dengan melihat tiga perspektif yaitu: (1) pelanggan;

(2) internal bisnis proses; dan

pembelajaran dan pertumbuhan.

\section{Uji Validitas}

Menurut Ghozali (2016), uji validitas penelitian ini digunakan untuk melihat sah atau valid tidaknya suatu kuesioner. Nilai $r$ tabel diperoleh dari degree of freedom $(\mathrm{df})=$ $\mathrm{n}$ - 2. Dalam hal ini $\mathrm{n}$ adalah jumlah sampel responden $100-2=98$ dan alpha $=0,05$. Nilai $r$ tabel yang didapat adalah 0,197.

Hasil uji validitas ketiga perspektif non keuangan yang diteliti, disajikan pada Tabel 3 sampai dengan 5 di bawah ini.

\section{Tabel 3}

\section{Hasil Uji Validitas - Pelanggan}

\begin{tabular}{|c|c|c|c|}
\hline $\begin{array}{c}\text { Kode } \\
\text { Pertanyaan }\end{array}$ & $\begin{array}{c}\mathbf{r} \\
\text { hitung }\end{array}$ & $\begin{array}{c}\mathbf{r} \\
\text { tabel }\end{array}$ & Keterangan \\
\hline C1 & 0,852 & 0,197 & Valid \\
\hline C2 & 0,839 & 0,197 & Valid \\
\hline C3 & 0,253 & 0,197 & Valid \\
\hline C4 & 0,735 & 0,197 & Valid \\
\hline C5 & 0,853 & 0,197 & Valid \\
\hline C6 & 0,807 & 0,197 & Valid \\
\hline C7 & 0,853 & 0,197 & Valid \\
\hline C8 & 0,859 & 0,197 & Valid \\
\hline C9 & 0,871 & 0,197 & Valid \\
\hline C10 & 0,817 & 0,197 & Valid \\
\hline
\end{tabular}

Sumber: Data dioalah penulis, tahun 2018
Tabel 4

Hasil Uji Validitas - Internal Bisnis Proses

\begin{tabular}{|c|c|c|c|}
\hline Kode Pertanyaan & $\mathbf{r}$ Hitung & $\mathbf{r}$ Tabel & Keterangan \\
\hline IBP1 & 0,987 & 0,197 & Valid \\
\hline IBP2 & 0,961 & 0,197 & Valid \\
\hline IBP3 & 0,891 & 0,197 & Valid \\
\hline IBP4 & 0,961 & 0,197 & Valid \\
\hline IBP5 & 0,987 & 0,197 & Valid \\
\hline IBP6 & 0,988 & 0,197 & Valid \\
\hline
\end{tabular}

Sumber: Data dioalah penulis, tahun 2018

Tabel 5

Hasil Uji Validitas - Pembelajaran dan Pertumbuhan

\begin{tabular}{|c|c|c|c|}
\hline Kode Pertanyaan & r Hitung & r Tabel & Keterangan \\
\hline LG1 & 0,872 & 0,197 & VALID \\
\hline LG2 & 0,852 & 0,197 & VALID \\
\hline LG3 & 0,873 & 0,197 & VALID \\
\hline LG4 & 0,693 & 0,197 & VALID \\
\hline LG5 & 0,873 & 0,197 & VALID \\
\hline LG6 & 0,686 & 0,197 & VALID \\
\hline LG7 & 0,406 & 0,197 & VALID \\
\hline LG8 & 0,463 & 0,197 & VALID \\
\hline
\end{tabular}

Sumber: Data dioalah penulis, tahun 2018

Berdasarkan tabel di atas terlihat bahwa seluruh instrument pertanyaan memiliki nilai $r$ hitung yang lebih besar dari $r$ tabel. Dengan demikian seluruh instrumen pertanyaan yang digunakan adalah valid.

\section{Uji Reliabilitas}

Uji reliabilitas digunakan untuk menguji konsistensi data dalam jangka waktu tertentu dimana apabila Cronbach Alpha > 0,70 yang berarti bahwa instrumen tersebut dapat digunakan sebagai pengumpulan data yang handal (Ghozali, 2013: 48). 
Pratiwi dan Elok Kurniawati/ Jurnal Ilmiah Wahana Akuntansi, 14 (1) 2019, 65-84

Hasil uji reliabilitas ketiga perspektif non keuangan yang diteliti, disajikan pada Tabel 6 di bawah ini.

\section{Tabel 6}

\section{Hasil Uji Reliabilitas}

\begin{tabular}{|c|c|c|c|}
\hline Variabel & $\begin{array}{c}\text { Cronbach's } \\
\text { alpha }\end{array}$ & Acuan & Keterangan \\
\hline C & 0,921 & 0,70 & Reliabel \\
\hline IBP & 0,983 & 0,70 & Reliabel \\
\hline LG & 0,854 & 0,70 & Reliabel \\
\hline
\end{tabular}

Sumber: Data dioalah penulis, tahun 2018

Berdasarkan tabel di atas dapat dilihat bahwa semua variabel memiliki nilai cronbach's alpha di atas 0,70 yang disimpulkan reliabel.

\section{Prespektif Pelanggan}

Hasil rekapan kuesioner perspektif pelanggan disajikan pada Lampiran 2.

Berdasarkan hasil rekapan kuesioner Pelanggan yang disajikan pada Lampiran 2, menunjukkan bahwa pada perspektif pelanggan secara keseluruhan rata-rata hasil yang diperoleh dari 100 responden dari 10 pernyataan yaitu sebesar $77 \%$. Dikarenakan hasil tersebut masuk dalam kategori interprestasi skor (61-80), maka kinerja perusahaan untuk prespektif pelanggan dikategorikan baik.

\section{Customer Statisfication}

Pengukuran ini dilakukan untuk mengetahui tingkat kepuasan pelanggan. Tingkat kepuasan pelanggan pun sangat penting bagi perusahaan. Apabila pelanggan sudah puas maka keberlangsungan perusahaan pun dapat berjalan terus karena hal ini dapat membuat tingkat loyalitas pelanggan dalam menggunakan produk PT Malindo Feedmill Tbk.

PT Malindo Feedmill Tbk pun selalu memberikan produk dan pelayanan yang terbaik kepada pelanggan. Dengan hal ini perusahaan mengharapakan pelanggan puas dengan semua produk yang dijual oleh perusahaan sehingga dapat terus membeli produknya.

Berdasarkan data pada Lampiran 1, dapat disimpulkan bahwa tingkat kepuasan pelanggan masuk dalam kategori yang baik, hal ini ditunjukkan dengan jawaban pelanggan atas pertanyaan "Apakah anda puas dengan kualitas produk PT Malindo Feedmill Tbk?" mendapatkan rata-rata skor $76 \%$ dan pertanyaan "Apakah anda puas dengan penyampaian mengenai produk PT Malindo Feedmill Tbk?" mendapatkan rata-rata skor $77 \%$. Karena kriteria interprestasi skor 61$80 \%$ adalah kategori baik.

\section{Market Share}

Pengukuran ini untuk melihat seberapa tingkat penguasaan segmen pasar yang dikuasai sebuah perusahaan. Melihat hasil dari Lampiran 2, poin pertanyaan "Setujukah Anda PT 
Pratiwi dan Elok Kurniawati/ Jurnal Ilmiah Wahana Akuntansi, 14 (1) 2019, 65-84

Malindo Feedmill Tbk \& Group memberikan produk terbaik dibanding perusahan sejenis lainnya?" memiliki rata-rata skor $71 \%$, sedangakan untuk pertanyaan "Apakah anda setuju PT Malindo Feedmill Tbk selalu menggali kebutuhan pelanggan?" mendapatkan skor $78 \%$. Jika dibandingkan dengan kriteria interprestasi skor $61 \%-80 \%$ dikatakan baik, maka PT Malindo Feedmill Tbk masih dikatakan baik dalam menguasai pangasa pasar.

Saat ini perusahaan PT Malindo Feedmill Tbk menjalankan usahanya terdiri dari empat divisi yaitu pembibitan ayam, peternakan ayam, pedaging, dan makanan olahan. Industri perunggasan ini menyuplai produk unggas berupa daging ayam dan telur yang merupakan sumber protein berkualitas dengan harga yang terjangkau (Sumber: Annual Report 2017: 42).

Untuk divisi pakan ternak memiliki tenaga layanan teknis yang memiliki pengetahuan dan keahlian khusus

dalam menerapkan managemen budidaya ternak yang baik dilapangan. PT Malindo Feedmill tbk selalu memastikan kualitas yang tinggi untuk produk-produknya dengan menerapakn ISO 9001 Quality Management System dan ISO 22000 Food Safety Manajemen.
Divisi makanan olahan telah mendapatkan akreditasi dan sertifikasi berupa sertifikat Halal dari MUI (Majelis ulama Indonesia), sertifikat ISO 9001 dan ISO 22000 Food Safety Manajemen System, dan sertifikat lisensi eksport ke Jepang.

Divisi pembibitan ayam pun sudah lolos sertifikasi SNI yang dilakukan oleh Lembaga Sertifikasi Produk Benih dan bibit Ternak (LS Pro) Ditjen Peternakan dan Kesehatan Hewan Kementrian Pertanian RI (Sumber: Annual report 2017: 43-46).

Melihat kondisi tersebut di atas PT Malindo Feedmill terus berusaha dalam menguasai segmen pasar dengan cara memberikan produk jual yang bervarian dan berkualitas terbaik Kepalada pelanggan. Namun dikarenakan usaha bisnisnya masih berkembang, maka perlu membuat srategi dalam menarik pelngganpelanggan baru dan meningkatkan branding di masyarakat seluruh Indonesia.

\section{Customer Retention}

Pengukuran ini untuk mengetahui seberapa besar tingkat perusahaan mempertahankan hubungan dengan pelanggan atau konsumen. Berdasarkan data pada Lampiran 2, poin pertanyaan “Apakah anda setuju PT Malindo Feedmill Tbk memberikan interaksi 
Pratiwi dan Elok Kurniawati/ Jurnal Ilmiah Wahana Akuntansi, 14 (1) 2019, 65-84

yang menyenangkan?" mendapatkan rata-rata 77\%, dan pernyataan “Apakah anda setuju PT Malindo Feedmill Tbk memberikan kemudahan dalam transaksi?" mendapatkan rata-rata $78 \%$, sehingga masuk dalam kategori sangat baik. Oleh karena itu, tingkat kepuasan pelanggan selain produk yang baik maka berpengaruh besar juga terhadap hubungan atau relasi yang diberikan marketing kepada pelanggan.

PT Malindo Feedmill Tbk telah memiliki sistem pemasaran yang handal dan berdedikasi dalam melayani pelanggan yang ingin membeli produk usahanya. Disisi lain pun, pelanggan merasa puas dalam bertransaksi baik ketika pembelian maupun pembayaran produk. Hal ini karena tim pemasaran memudahkan konsumen untuk melakukan pemesanan dengan cari melalui email sehingga mempersingkat waktu dalam pemesanan sehingga ketika produk sudah disiapkan maka pelanggan segera ambil disetiap cabang perusahaan dan tidak perlu menunggu lama, serta untuk pembayarannya pelanggan pun dimudahkan dengan cara melakukan transfer ke rekening virtual account yang dibuat untuk tiap pelanggannya, serta tersedia EDC jika diperlukan pembayaran dengan cara debet.

\section{Customer Acquisition}

Pengukuran ini untuk mengukur kemampuan perusahaan dalam menarik pelanggan baru atau memenangkan bisnis baru. Berdasarkan hasil pada Lampiran 2, poin pertanyaan "Apakah anda setuju PT Malindo Feedmill Tbk sudah optimal dalam menarik pelanggan baru?" rata-rata skor sebesar $79 \%$ dan poin pertanyaan "Apakah anda setuju PT Malindo Feedmill Tbk selalu memberikan promosi produk yang menarik?" rata-rata skor sebesar $79 \%$, sehingga usaha dalam menarik pelanggan baru masih dikatan cukup baik.

Dikarenakan masih dalam proses berkembang dan memasarkan brand dari setiap produk yang disediakan, PT Malindo feedmill selalu senantiasa berusaha dalam menarik pelanggan baru. Dengan hal ini jika banyak pelanggan yang sudah mengetahui produknya dan tingkat loyalitasnya sudah ada maka akan meningkatkan keberlangsungan usahanya dan tetap bisa menghadapi para pesaing yang memiliki bidang usaha yang sama.

\section{Customer Profitability}

Pengukuran ini mengukur seberapa besar keuntungan yang diperoleh PT Malindo Feedmill Tbk dari produk yang ditawarkan kepada konsumen. Dengan data yang didapat pada tabel 4.3, untuk pertanyaan "Apakah anda 
Pratiwi dan Elok Kurniawati/ Jurnal Ilmiah Wahana Akuntansi, 14 (1) 2019, 65-84

setuju karyawan PT Malindo Feedmill Tbk selalu menjual produk secara profesional?" mendapatkan rat-rata skor $80 \%$, dan pertanyaan "Setujukah Anda PT Malindo Feedmill Tbk selalu memberikan proses jual-beli produk secara cepat?" mendapatkan rata-rata skor $78 \%$, sehingga dapat dikatakan baik.

Pihak manajemen selalu berusaha memberikan keuntungan kepada pelanggan salah satunya dengan cara calim kerugian. Jika ada produk yang diterima rusak atau mengalami kematian maka dapat melakukan claim terhadap barang tersebut, namun untuk pemberian klaim tersebut pun dengan cara meberikan potongan harga namun diperhitungannya tetap harus dipertimbangkan agar tidak mengurangi laba perusahaan.

Apabila pelanggan merasa diuntungkan dan merasa puas dengan produk yang sudah dibeli maka berdampak positif dalam meningkatkan loyalitas pelanggan sehingga kemungkinan dapat terus memberikan keuntungan yang besar kepada perusahaan.

\section{Prespektif Internal Bisnis Proses}

Hasil rekapan kuesioner perspektif internal bisnis proses disajikan pada Lampiran 3.
1. Proses Inovasi

Pengukuran ini untuk mengukur kemampuan perusahaan dalam menciptakan produk yang baru terhadap total produk yang ditawarkan. Berdasarkan data pada Lampiran 3 untuk pertanyaan "Setujukah anda PT MF Tbk selalu mengupdate komponen pendukung operasional secara berkala?" rata-rata skor sebesar $76 \%$ dan pertanyaan "Apakah anda setuju PT MF Tbk menyediakan produk yang beraneka ragam?" rata-rata skor sebesar $77 \%$, karena rata-rata skor tersebut masuk dalam kategori interprestasi skor 60\%-81\% maka PT Malindo Feedmill Tbk dapat mampu menciptakan inovasi produknya dalam mengembangkan usahanya dan memenuhi kebutuhan pelanggannya. Hal ini terbukti dengan munculnya produk baru di divisi makanan olahan yang ditujukukan ke segmen pasar sesuai dengan kualitas harganya.

Sebelumnya produk makanan olahan "Sunny Gold" dipasarkan untuk kalangan atas dimana kualitas yang diberikan sangat baik dan harga relatif lebih mahal. Namun untuk memenuhi keiingan pelanggan, PT Malindo Feedmill Tbk mengeluarkan produk MFD lagi dengan merek Ciki Wiki, dan Viena. Merek tersebut dibuat untuk ditujukan kepada segmen pasar 
Pratiwi dan Elok Kurniawati/ Jurnal Ilmiah Wahana Akuntansi, 14 (1) 2019, 65-84

dikalangan menengah dan bawah.

Dimana harga yang diberikan relatif terjangkau dan kualitas pun tetap dijaga dan berkualitas baik.

2. Proses Operasi

Pengukuran ini untuk Mengukur seberapa besar tingkat kualitas produk yang diberikan kepada pelanggan. Berdasarkan data pada Lampiran 3 untuk pertanyaan "Setujukah PT MF

Tbk telah melakukan proses penyelesaian kegiatan operasional dengan efektif dan efisien?" rata-rata skor $75 \%$, dan petanyaan "Setujukah anda PT MF Tbk profesional dalam menghadapi pihak pelanggan?" ratarata skor sebesar $76 \%$. Rata-rata skor tersebut masuk kedalam kategori interprestasi skor $61 \%-80 \%$ dengan kategori baik.

Dalam melakukan proses operasinya PT Malindo Feedmill Tbk selalu memberikan kualitas produk terbaik dengan dibantu dengan karyawan yang memiliki keahlian yang baik dalam mendukung operasionalnya.

Saat ini dalam menjalankan bisnis usahanya PT Malindo Feedmill Tbk menerapkan ISO 9001 Quality Manajemen System dan ISO 22000 Food Safety Management. Dengan ini, kinerja perusahaan diharapkan dapat sesuai dengan standar operasinal yang ada sehingga dapat mencapai tujuan perusahaan dengan efektif dan efisien.

3. Proses Layanan Purnajual

Pengukuran ini untuk mengukur tingkat nilai tambah bagi keseluruhan proses bisnis internal perusahaan PT Malindo Feedmill Tbk. Untuk pertanyaan "Setujukah Anda PT MF Tbk selalu memberikan kualiltas yang baik dalam menangani keluhan pelanggan?" rata-rata skor sebesar $77 \%$ dan pertanyaam "Setujukah Anda jika PT MF Tbk bekerja sama dengan perusahaan asuransi dapat mendukung operasional bisnisnya?" rata-rata skor sebesar $78 \%$. Rata-rata tersebut masuk dalam kategori interprestasi Baik.

PT Malindo Feedmill memiliki layanan purna jual berupa adanya Customer Service Officer (CSO) yang disediakan untuk melayani pelanggan jika ada keluhan. Dengan adanya layanan ini dapat membuktikan bahwa ada usaha perusahaan dalam memberikan nilai tambah untuk mendukung keberlangsungan usahanya.

\section{Prespektif Pembelajaran dan Pertumbuhan \\ Hasil rekapan kuesioner perspektif pembelajaran dan pertumbuhan disajikan pada Lampiran 4.}

1. Produktivitas karyawan 
Pratiwi dan Elok Kurniawati/ Jurnal Ilmiah Wahana Akuntansi, 14 (1) 2019, 65-84

Pengukuran ini untuk mengukur tingkat produktifitas kerja karyawan perusahaan dalam bekerja pada PT Malindo Feedmill Tbk. Melihat hasil dari Lampiran 4 hasil rata-rata skor yang di dapat sebesar $77 \%, 70 \%$, dan $75 \%$ untuk variable tingkat produktivitas karyawan. Berhubung hasil rata-rata tersebut masuk dalam kriteria interprestasi skor 61\%-80\%, maka kinerja perusahaan di variabel produktivitas karyawan yaitu baik.

Dengan demikian produktifitas karyawan saat ini cukup berpengaruh baik dalam pengukuran kinerja bagi perusahaan.

2. Pelatihan karyawan

Pengukuran ini untuk mengukur seberapa sering perusahaan memberikan pelatihan dengan pengembangan kepada sumber daya manusia yang dimilikinya. Melihat hasil yang terdapat pada Lampiran 4 hasil rata-rata skor yang di dapat sebesar $79 \%$, dan $78 \%$ untuk tingkat produktivitas karyawan. Hasil rata-rata ini masuk dalam kriteria interprestasi skor $61 \%-80 \%$, maka kinerja perusahaan di variabel pelatihan karyawan yaitu baik. Hal ini dibutikan dengan adanya aktivitas yang dilakukan HRD yaitu melakukan beberapa pelatihan untuk tiap karyawan dapat berpengaruh dalam meningkatkan soft skill dan hard skill.

Disisi lain, tiap divisi pun saling sharing knowledge satu sama lain untuk meningkatkan kinerjanya. Dengan hasil skor tersebut dapat dikatakan bahwa pelatihan karyawan cukup berpengaruh baik dalam pengukuran kinerja perusahaan.

3. Kepuasan Karyawan

Pengukuran ini untuk mengukur seberapa besar tingkat kepuasan karyawan selama bekerja dalam suatu perusahaan. Melihat hasil dari data yang disajikan pada Lampiran 4, hasil rata-rata skor yang di dapat sebesar, $71 \%$, 67\% dan 68\% untuk tingkat kepuasan karyawan. Walaupun hasil rata-rata skor untuk variabel kepuasan karyawan lebih rendah dibanding yang lain, namun masih masuk dalam kriteria interprestasi skor $61 \%-80 \%$ yaitu kategori baik.

Melihat kondisi ini pihak perusahaan dapat mengevaluasi terkait kepuasan karyawan terhadap tunjangan dan reward yang didapat oleh karyawan bila kinerjanya baik. Dengan adanya tunjangan yang mencukupi dan reward bagi keryawan berprestasi, maka akan berdampak positif untuk kinerja karyawan tersebut, sehingga kinerja yg didapat lebih maksimal. 
Pratiwi dan Elok Kurniawati/ Jurnal Ilmiah Wahana Akuntansi, 14 (1) 2019, 65-84

\section{KESIMPULAN DAN SARAN}

\section{Kesimpulan}

Berdasarkan hasil analisis dan pembahasan yang telah diuraikan maka dapat disajikan beberapa kesimpulan dari hasil analisi yaitu sebagai berikut:

1. Dari hasil analisis penilaian kinerja keuangan pada PT Malindo Feedmill Tbk, perspektif keuangan terlihat fluktuatif sejak 2015-2017. Dengan

penilaian beberapa rasio-rasio keuangan di tahun 2017 mendapatkan hasil positif, yang artinya perusahaan masih dinilai cukup baik dalam mengelola keberlangsungan usahanya dari segi keuangan, seperti halnya dalamkemampuanpembayaran kewajiban jangka pendeknya, pengelolaan asset, serta kemampuan dalam mendapatkan laba.

2. Hasil analisis penilaian kinerja perusahaan dari segi perspektif pelanggan menunjukan hasil yang baik, yakni tingkat kupuasan pelanggan masuk dalam kategori puas. Kondisi ini menunjukkan bahwa PT Malindo Feedmill Tbk mampu memberi kepuasan kepada pelanggannya dan mampu berlomba dalam menguasi segmen pasar dibidang yang sama. Hasil uji dan reliabilitas untuk data kuisioner dengan sepuluh pernyataan menunjukan hasil yang valid \& reliabel.
3. Hasil analisis penilaian kinerja perusahaan dari segi perspektif internal bisnis proses menunjukan hasil yang baik. Hal ini menunjukkan bahwa PT Malindo feedmill selalu berinovasi untuk memenuhi keinginn konsumen dan berupaya menjalankan proses usahanya dengan efektif dan efisien serta memberikan layanan purna jual sebagai nilai tambah. Hasil uji dan reliabilitas untuk data kuesioner ini dengan enam pernyataan menunjukan hasil yang valid dan reliabel.

4. Hasil analisis penilaian kinerja perusahaan dari segi perspektif pembelajaran dan pertumbuhan menunjukan hasil cukup baik. Hal ini berarti dengan adanya training maupun sharing knowledge bagi karyawan berdampak baik dalam meningkarkan kinerja perusahaannya. Untuk kepuasan karyawan menghasilkan hasil yang relatif rendah. Hasil uji dan reliabilitas untuk data kuesioner ini dengan delapan pernyataan menunjukan hasil yang valid dan reliabel

\section{Saran}

Diharapkan kepada PT Malindo Feedmill Tbk untuk penerapan penilaian kinerja dengan metode Balance Scorecard agar dapat dijalankan kedepannya guna sebagai tolak ukur kinerja perusahaan, dan hasil tersebut dapat digunakan sebagai bahan evaluasi 
Pratiwi dan Elok Kurniawati/ Jurnal Ilmiah Wahana Akuntansi, 14 (1) 2019, 65-84

manajemen untuk meningkatkan kualitas kinerja yang baik demi mencapai tujuannya. Khususnya, untuk prespektif keuangan dan perspektif pembelajaran dan pertumbuhan agar dapat ditingkatkan lagi.

\section{DAFTAR PUSTAKA}

Anthony, N. Robert dan Govindarajan, Vijay. (2012). Sistem Pengendalian Manajemen.Jilid 2. Jakarta:

Salemba Empat.

Anthony, N. Robert dan Govindarajan, Vijay. (2016). Sistem Pengendalian Manajemen. Jilid 1.Jakarta: Salemba Empat.

Atkinson, et al. (2012). Akuntansi Manajemen. Edisi Kelima. Jilid 2. Jakarta: PT INDEKS.

Ghozali, Imam, dan Anis Chariri. (2016). Teori Akuntansi. Semarang: Badan Penerbit Universitas Diponegoro.

Handoko, Dr. T. Hani. (2012). Manajemen. Edisi 2. Yogyakarta: BPFE-Yogyakarta.

Lako, Andreas. (2011). Dekonstruksi CSR \& Reformasi Paradigma Bisnis \& Akuntansi. Jakarta: Erlangga.

Parmenter, David. (2014). Mengembangkan, Mengimplementasikan dan Menggunakan KPI Cetakan II. Jakarta: PPM.

Pasolong, Harbani. (2013). Teori administrasi publik. Bandung: Alfabeta.

Rangkuti, Freddy. (2013). SWOT Balance Scorecard, Teknik Menyusun Startegi Korporat yang Efektif plus Cara Mengelola Kinerja dan Risiko. Jakarta: PT Gramedia Pustaka Utama.
Sugiyono. (2013). Metode Penelitian Pendidikan Pendekatan Kuantitatif, Kualitatif, dan R\&D. Bandung: ALFABETA.

Wibowo, (2011). Manajemen Perubahan. Jakarta: PT. RajaGrafindo Persada.

www.kompas.com 
Lampiran 1: Operasionalisasi Variabel

\begin{tabular}{|c|c|c|c|c|}
\hline $\begin{array}{c}\text { VARIABEL } \\
\text { UTAMA }\end{array}$ & $\begin{array}{c}\text { SUB } \\
\text { VARIABEL }\end{array}$ & $\begin{array}{c}\text { KONSEP } \\
\text { VARIABEL }\end{array}$ & INDIKATOR & $\begin{array}{c}\text { SKALA } \\
\text { PENGUKURAN }\end{array}$ \\
\hline \multirow{4}{*}{$\begin{array}{l}\text { Penerapan } \\
\text { Balance } \\
\text { Scorecard }\end{array}$} & Financial & $\begin{array}{l}\text { Tujuan finansial } \\
\text { menyajikan suatu fokus } \\
\text { untuk tujuan dan } \\
\text { ukuran dalam seluruh } \\
\text { perspektif BSC. Setiap } \\
\text { ukuran dipilih harus } \\
\text { menjadi bagian dari } \\
\text { suatu hubungan } \\
\text { sebabakibat yang } \\
\text { memuncak dalam } \\
\text { peningkatan } \\
\text { performans keuangan }\end{array}$ & $\begin{array}{l}\text { 1. Current Ratio } \\
\text { 2. Net Profit } \\
\text { Margin } \\
\text { 3. ROA } \\
\text { 4. ROE }\end{array}$ & Rasio \\
\hline & Customer & $\begin{array}{l}\text { Menyelaraskan } \\
\text { berbagai ukuran } \\
\text { pelanggan penting } \\
\text { yaitu kepuasan, retensi, } \\
\text { loyalitas, akuisisi dan } \\
\text { profitabilitas dari } \\
\text { pelanggan dan segmen } \\
\text { pasar sasaran. }\end{array}$ & 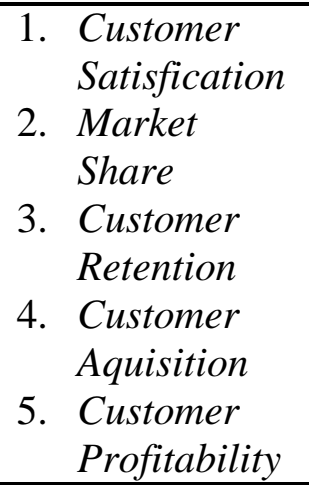 & Skala Likert \\
\hline & $\begin{array}{l}\text { Internal } \\
\text { Bussiness } \\
\text { Process }\end{array}$ & $\begin{array}{l}\text { terciptanya langkah } \\
\text { sistematis dan pola } \\
\text { pikir pengukuran } \\
\text { proses bisnis internal } \\
\text { yang mampu } \\
\text { mendorong tercapainya } \\
\text { tujuan yang ditetapkan } \\
\text { bagi pelanggan dan } \\
\text { pemegang saham } \\
\end{array}$ & $\begin{array}{ll}\text { 1. } & \text { Proses } \\
\text { Inovasi } \\
\text { 2. Proses } \\
\text { Operasi } \\
\text { 3. Proses } \\
\text { Layanan } \\
\text { Purna Jual }\end{array}$ & Skala Likert \\
\hline & $\begin{array}{l}\text { Learn and } \\
\text { Growth }\end{array}$ & $\begin{array}{l}\text { Ditekankan untuk } \\
\text { mempelajari lebih } \\
\text { dalam sumber daya } \\
\text { yang dapat diandalkan } \\
\text { untuk bersaing di } \\
\text { lingkungan bisnis yang } \\
\text { kompetitif, dan } \\
\text { meletakkan pada } \\
\text { sumber daya yang } \\
\text { mampu menempatkan } \\
\text { perusahaan pada posisi } \\
\text { daya saing dalam } \\
\text { jangka panjang }\end{array}$ & $\begin{array}{l}\text { 1. Produktivitas } \\
\text { Karyawan } \\
\text { 2. Pelatihan } \\
\text { Karyawan } \\
\text { 3. Kepuasan } \\
\text { Karyawan }\end{array}$ & Skala Likert \\
\hline
\end{tabular}


Pratiwi dan Elok Kurniawati/ Jurnal Ilmiah Wahana Akuntansi, 14 (1) 2019, 65-84

\section{Lampiran 2: Rekap Hasil Kuesioner Perspektif Pelanggan}

\begin{tabular}{|c|c|c|c|c|c|c|c|c|c|c|c|}
\hline Sub Variable & \multicolumn{2}{|c|}{ Customer Statisfication } & \multicolumn{2}{|c|}{ Market Share } & \multicolumn{2}{|c|}{ Customer Retention } & \multicolumn{2}{|c|}{ Customer Acquisition } & \multicolumn{2}{|c|}{ Customer Profitability } & \\
\hline Kode & $\mathrm{C} 1$ & $\mathrm{C} 2$ & $\mathrm{C} 3$ & $\mathrm{C} 4$ & C5 & $\mathrm{C} 6$ & C7 & $\mathrm{C} 8$ & C9 & $\mathrm{C} 10$ & \\
\hline Pertanyaan & $\begin{array}{c}\text { Apakah anda } \\
\text { puas dengan } \\
\text { kualitas produk } \\
\text { PT Malindo } \\
\text { Feedmill Tbk? }\end{array}$ & $\begin{array}{c}\text { Apakah anda } \\
\text { puas dengan } \\
\text { penyampaian } \\
\text { mengenai } \\
\text { produk PT } \\
\text { Malindo } \\
\text { Feedmill Tbk? }\end{array}$ & $\begin{array}{c}\text { Setujukah } \\
\text { Anda PT MF } \\
\text { \& Group } \\
\text { memberikan } \\
\text { produk terbaik } \\
\text { dibanding } \\
\text { perusahan } \\
\text { sejenis lainnya? }\end{array}$ & \begin{tabular}{|c|} 
Apakah anda \\
setuju PT \\
Malindo \\
Feedmill Tbk \\
selalu menggali \\
kebutuhan \\
pelanggan?
\end{tabular} & $\begin{array}{c}\text { Apakah anda } \\
\text { setuju PT } \\
\text { Malindo } \\
\text { Feedmill Tbk } \\
\text { memberikan } \\
\text { interaksi yang } \\
\text { menyenangkan? }\end{array}$ & $\begin{array}{l}\text { Apakah anda } \\
\text { setuju PT } \\
\text { Malindo } \\
\text { Feedmill Tbk } \\
\text { memberikan } \\
\text { kemudahan } \\
\text { dalam } \\
\text { transaksi? }\end{array}$ & $\begin{array}{c}\text { Apakah anda } \\
\text { setuju PT } \\
\text { Malindo } \\
\text { Feedmill Tbk } \\
\text { sudah optimal } \\
\text { dalam menarik } \\
\text { Pelanggan } \\
\text { baru? }\end{array}$ & $\begin{array}{c}\text { Apakah anda } \\
\text { setuju PT } \\
\text { Malindo } \\
\text { Feedmill Tbk } \\
\text { selalu } \\
\text { memberikan } \\
\text { promosi } \\
\text { produk yang } \\
\text { menarik? }\end{array}$ & $\begin{array}{c}\text { Apakah anda } \\
\text { setuju } \\
\text { karyawan PT } \\
\text { Malindo } \\
\text { Feedmill Tbk } \\
\text { selalu menjual } \\
\text { produk secara } \\
\text { profesional? }\end{array}$ & $\begin{array}{c}\text { Setujukah } \\
\text { Anda PT } \\
\text { Malindo } \\
\text { Feedmill Tbk } \\
\text { selalu } \\
\text { memberikan } \\
\text { proses jual-beli } \\
\text { produk secara } \\
\text { cepat? }\end{array}$ & $\begin{array}{l}\text { Total } \\
\text { Perspektif }\end{array}$ \\
\hline Skor Total & 382 & 386 & 356 & 388 & 383 & 392 & 393 & 393 & 398 & 391 & 3862 \\
\hline Rata-rata & $76 \%$ & $77 \%$ & $71 \%$ & $78 \%$ & $77 \%$ & $78 \%$ & $79 \%$ & $79 \%$ & $80 \%$ & $78 \%$ & $77 \%$ \\
\hline $\begin{array}{c}\text { Keterangan } \\
\text { Berdasarkan } \\
\text { Skala likert }\end{array}$ & Baik & Baik & Baik & Baik & Sangat Baik & Baik & Baik & Baik & Baik & Baik & Baik \\
\hline
\end{tabular}




\section{Lampiran 3: Rekap Hasil Kuesioner Perspektif Internal Bisnis Proses}

\begin{tabular}{|c|c|c|c|c|c|c|c|}
\hline Sub Variable & \multicolumn{2}{|c|}{ Proses Inovasi } & \multicolumn{2}{|c|}{ Proses Operasi } & \multicolumn{2}{|c|}{ Proses Layanan Purna Jual } & \\
\hline Kode & IBP1 & IBP2 & IBP3 & IBP4 & IBP5 & IBP6 & \\
\hline Pertanyaan & $\begin{array}{l}\text { Setujukah anda } \\
\text { PT MF Tbk } \\
\text { selalu } \\
\text { mengupdate } \\
\text { komponen } \\
\text { pendukung } \\
\text { operasional } \\
\text { secara berkala? }\end{array}$ & $\begin{array}{c}\text { Apakah anda } \\
\text { setuju PT MF } \\
\text { Tbk } \\
\text { menyediakan } \\
\text { produk yang } \\
\text { beraneka } \\
\text { ragam? }\end{array}$ & $\begin{array}{c}\text { Setujukah PT } \\
\text { MF Tbk telah } \\
\text { melakukan } \\
\text { proses } \\
\text { penyelesaian } \\
\text { kegiatan } \\
\text { operasional } \\
\text { dengan efektif } \\
\text { dan efisien? }\end{array}$ & $\begin{array}{c}\text { Setujukah anda } \\
\text { PT MF Tbk } \\
\text { profesional } \\
\text { dalam } \\
\text { menghadapi } \\
\text { pihak } \\
\text { pelanggan? }\end{array}$ & $\begin{array}{c}\text { Setujukan Anda } \\
\text { PT MF Tbk } \\
\text { selalu } \\
\text { memberikan } \\
\text { kualiltas yang } \\
\text { baik dalam } \\
\text { menangani } \\
\text { keluhan } \\
\text { pelanggan? }\end{array}$ & $\begin{array}{c}\text { Setujukah Anda } \\
\text { jika PT MF } \\
\text { Tbk bekerja } \\
\text { sama dengan } \\
\text { perusahaan } \\
\text { asuransi dapat } \\
\text { mendukung } \\
\text { operasional } \\
\text { bisnisnya? }\end{array}$ & $\begin{array}{c}\text { Total } \\
\text { Perspektif }\end{array}$ \\
\hline Skor Total & 379 & 383 & 373 & 379 & 386 & 388 & 2288 \\
\hline Rata-rata & $76 \%$ & $77 \%$ & $75 \%$ & $76 \%$ & $77 \%$ & $78 \%$ & $458 \%$ \\
\hline $\begin{array}{c}\text { Keterangan } \\
\text { Berdasarkan } \\
\text { Skala likert }\end{array}$ & Baik & Baik & Baik & Baik & Baik & Sangat Baik & Baik \\
\hline
\end{tabular}


Pratiwi dan Elok Kurniawati/ Jurnal Ilmiah Wahana Akuntansi, 14 (1) 2019, 65-84

\section{Lampiran 4: Rekap Hasil Kuesioner Perspektif Pembelajaran dan Pertumbuhan}

\begin{tabular}{|c|c|c|c|c|c|c|c|c|c|}
\hline \multirow{2}{*}{$\frac{\text { Sub Variable }}{\text { Kode }}$} & \multicolumn{3}{|c|}{ Produktivitas Karyawan } & \multicolumn{2}{|c|}{ Pelatihan Karyawan } & \multicolumn{3}{|c|}{ Kepuasan Karyawan } & \\
\hline & LG1 & LG2 & LG3 & LG4 & LG5 & LG6 & LG7 & LG8 & \\
\hline Pertanyaan & $\begin{array}{c}\text { Setujukah } \\
\text { Anda sudah } \\
\text { memahami } \\
\text { tentang produk } \\
\text { PT MF Tbk? }\end{array}$ & $\begin{array}{c}\text { Setujukah anda } \\
\text { selalu } \\
\text { mengembangkan } \\
\text { inisiatif dalam } \\
\text { meingkatkan } \\
\text { potensi kinerja? }\end{array}$ & \begin{tabular}{|c} 
Apakah anda \\
selalu \\
profesional \\
dalam \\
menyelesaikan \\
tugas sesuai \\
dengan \\
tanggung \\
jawabnya? \\
\end{tabular} & $\begin{array}{c}\text { Apakah anda } \\
\text { setuju Training } \\
\text { yg Anda dapat } \\
\text { bisa } \\
\text { meningkatkan } \\
\text { soft skill dan } \\
\text { hard skill untuk } \\
\text { menunjang } \\
\text { kinerja Anda? } \\
\end{array}$ & $\begin{array}{c}\text { Apakah anda } \\
\text { setuju sharing } \\
\text { knowledge } \\
\text { yang dilakukan } \\
\text { per divisi dapat } \\
\text { meningkatkan } \\
\text { kinerja Anda? }\end{array}$ & $\begin{array}{c}\text { Setujukah } \\
\text { Anda fasilitas } \\
\text { yang diberikan } \\
\text { sudah memadai } \\
\text { dalam } \\
\text { menunjang } \\
\text { kinerja Anda? }\end{array}$ & $\begin{array}{c}\text { Apakah Anda } \\
\text { Setuju } \\
\text { tunjangan yang } \\
\text { didapat sudah } \\
\text { sepadan } \\
\text { dengan kinerja } \\
\text { yang Anda } \\
\text { berikan ke PT } \\
\text { MF Tbk? }\end{array}$ & $\begin{array}{c}\text { Setujukah } \\
\text { Anda PT MF } \\
\text { Tbk selalu } \\
\text { memberikan } \\
\text { penghargaan } \\
\text { bagi karyawan } \\
\text { bila kerjanya } \\
\text { bagus? }\end{array}$ & $\begin{array}{c}\text { Total } \\
\text { Perspektif }\end{array}$ \\
\hline Skor Total & 387 & 351 & 374 & 397 & 388 & 353 & 337 & 338 & 2925 \\
\hline Rata-rata & $77 \%$ & $70 \%$ & $75 \%$ & $79 \%$ & $78 \%$ & $71 \%$ & $67 \%$ & $68 \%$ & $73 \%$ \\
\hline $\begin{array}{c}\text { Keterangan } \\
\text { Berdasarkan } \\
\text { Skala likert }\end{array}$ & Baik & Baik & Baik & Baik & Baik & Baik & Baik & Baik & Baik \\
\hline
\end{tabular}

